\title{
Los Comentarios reales de los incas: El credo católico como clave hermenéutica y el enfoque providencialista como mecanismo historiográfico
}

\author{
Carlos Piccone Camere \\ University of London
}

\author{
Vengo desde la América española, \\ a ofrendar este libro, en que se siente \\ latir un corazón... \\ José Santos Chocano $(1962,43)$
}

\section{Introducción}

Los Comentarios reales de los incas ${ }^{1}$ (en el presente trabajo se utilizará la edición de 2015 y solo se citará el nombre abreviado de la obra: CR) constituyen un texto de inapreciable valor tanto desde el punto de vista histórico como literario. La obra consagró a Gómez Suárez de Figueroa -primigenio nombre de quien pasaría a la posteridad como el Inca Garcilaso de la Vega (Cusco, 1539-Córdoba, 1616)- como uno de los exponentes máximos de las letras hispanoamericanas. Tal fue el juicio unánime de un selecto elenco de intelectuales peruanos de la talla de José de la Riva Agüero (1908, 135-137) Raúl Porras Barrenechea (1946) o Luis Alberto Sánchez (1979), cuyos dictámenes laudatorios bien podrían confluir en las líneas de otro eminente garcilasista:

\footnotetext{
1 El título explicativo original es, según el uso de la época, más prolijo: Primera parte de los Commentarios Reales, que tratan del origen de los Yncas, reyes que fueron del Perv, de sv idolatria, leyes y gouierno, en paz y en guerra: de sus vidas y conquistas, y de todo lo que fue aquel Imperio y su Republica, antes que los Españoles passaran a el. Escritos por el Ynca Garcilasso de la Vega, natural del Cozco, y capitan de su Magestad. Dirigidos a la Serenissima Princesa Doña Catalina de Portugal, Duqueza de Bargança, Ec. Con licencia de la Sancta Inquisicion, Ordinario, y Paço. (Lisboa, en la officina de Pedro Crasbeeck, 1609).

La segunda parte de los Comentarios reales, es decir, la Historia General del Perú, se publicó póstumamente en 1617. Véase un elenco de las principales ediciones de la obra garcilasista en: Aldo Albónico (1996). Una bibliografía actualizada y selecta sobre el Inca Garcilaso puede encontrarse en: López, Ortiz y Firbas (2016).
} 
Los Comentarios reales del Inca Garcilaso de la Vega inician, con robustos e inconfundibles caracteres, la literatura del Perú; son la primera obra de un natural del Nuevo Mundo que marca su huella con firmeza en la literatura occidental; y, por su autor y por su tema, no solo presentan un desfile de sucesos externos, sino constituyen el primer retrato espiritual de la vida peruana hecho por un mestizo de español y de india (Miró, 1971, p. 355).

Otras «historias» análogas ya habían sido escritas antes e, igualmente, constituyen fuentes valiosas para ponderar, a través de un estudio comparativo, el devenir histórico del incanato (Arista, 1989) En efecto, destacan las plumas de Pedro Cieza de León (c. 1520-1554), el «príncipe de los cronistas peruanos», quien se estremecía ante la envergadura abrumadora de los eventos que se propuso documentar (Cieza de León, 1998); Juan Diez de Betanzos (c. 1510-1576), meticuloso compilador de las fuentes indígenas, cuya labor historicista se vertebró en torno a la vida de los incas capaccuna, detallando particularmente el gobierno de Pachacútec Yupanqui, artífice de la conformación del Tahuantinsuyo (De Betanzos, 2003) Pedro Gutiérrez de Santa Clara (c. 1522-1603), oriundo de México, quien puso de relieve las guerras civiles entre los conquistadores del Perú; ${ }^{2}$ Pedro Pizarro (c. 1515-1587), cronista de páginas vívidas, capaz de retratar con igual solemnidad la dimensión divinizada de Atahualpa y la calidad de los vestidos de quienes le servían (Varón, 2008); y Agustín de Zárate (1514-1585), contador y cronista indiano quien cita clasicistamente a Platón, Plotino y Plutarco para narrar algunos de los hitos históricos más relevantes del incario en clave humanística (De Zárate, 1995).

No obstante, hay en el fondo y la forma de las letras del Inca un plus cualitativo difícilmente parangonable. En efecto, las notas de su narrativa «distinguen nítidamente a ese gran prosista renacentista de los escritores españoles de su tiempo» (Vargas, 2010b, 193-199). Prescott había expresado esta misma valoración a través de un cotejo sugestivo: «La diferencia que existe entre leer sus Comentarios y las narraciones de los escritores europeos es la misma que existe entre leer una obra en el [idioma] original y leerla en una traducción escueta» (Prescott, 2005, p. 881). Ya desde el Proemio al lector, Garcilaso quiso publicitarse a sí mismo explotando el carácter original de sus letras, que contrastaba con las limitaciones de sus pares, «españoles curiosos que han escrito [sobre] las repúblicas del Nuevo Mundo» (CR, «Proemio al lector», 16). Garcilaso creía poseer «más larga y clara noticia» que la que hasta entonces sus predecesores habían dado. No obstante, tuvo cuidado de manifestar que la razón verdadera que lo llevó a escribir sus Comentarios no había sido el contradecir a los historiadores europeos, «sino ser-

2 Gutiérrez de Santa Clara fue aclamado inicialmente por la crítica. Sin embargo, fue luego tendencialmente desprestigiado, especialmente a partir de los estudios de Bataillon quien lo calificó un hombre «de usurpada fama», un mero copista (Bataillon, 1961, 405). Lohmann tuvo un juicio más severo, considerando la obra del citado cronista como «un burdo corcusido de retazos de Jerez, Gómara, Zárate y El Palentino»» (Lohmann, 1999, p. 329). 
virles de comento y glosa y de intérprete en muchos vocablos indios, que, como extranjeros en aquella lengua, interpretaron fuera de la propiedad de ella». ${ }^{3}$

En los Comentarios reales el Inca montó una crítica epistemológica con la que enjuició a los historiadores que le precedieron. Utilizó para ello un método efectivo: asimiló todas las fuentes - propias y ajenas- que tuvo a su disposición para redactarlas bajo una impronta funcional a sus objetivos reivindicativos. ${ }^{4}$ En efecto, Garcilaso matizó y confirmó su visión providencialista de la historia a través de la cual quiso santiguar al imperio incaico. Así, por ejemplo, el Inca reprodujo en su propia versión historiográfica algunos textos de José de Acosta (1539-1600), ${ }^{5}$ Blas Valera (1547-1597) (Crowley, 1971) ${ }^{6}$ y Bartolomé de las Casas (1484-1566) (Crowley, 1971). Además, replicó con corrección explícita y remediadora las obras de Francisco López de Gómara (1511-1566) (Sobre algunos aspectos inéditos que relacionan al clérigo López de Gómara con la Orden de Alcántara, véase: Martínez, 2015, 151-176) y de Gonzalo Fernández de Oviedo (1478-1557), primer cronista de las Indias (K. A. Myers, 2007, p. 132). El cuzqueño, sin embargo, está lejos de ser un mero copista: su obra se fundamenta sobre sus fuentes primarias; aquellas que le podía ofrecer una cultura ágrafa como la inca. De esta manera, los relatos orales que le transmitieron sus familiares maternos y los conquistadores, amigos de su padre, proveyeron al Inca de una perspectiva privilegiada, haciéndolo capaz de descifrar arcanos incaicos: desde sus manifestaciones arquitectónicas y artísticas hasta sus liturgias seculares. Fue la constatación de la irremediable conquista del imperio materno, cuya cultura agonizaba, aquello que obligó a Garcilaso a hacer las veces de médium que, a través de sus dotes literarias, garantizara su pervivencia histórica.

\footnotetext{
3 Id. Del mismo modo, Garcilaso corrige a Pedro de Cieza: «Por ser español no sabía la lengua tan bien como yo, que soy indio Inca» (CR, lib. II, cap. II, 71). En efecto, el cronista cuzqueño conoce el quechua, a través del cual podrá incluso «declarar y hablar las palabras divinas, tan dulces y misteriosas» (CR, lib. VII, cap. III, p. 359). Sobre Garcilaso y la memoria oral, véase S. No (2006).

4 A semejanza de Guamán Poma de Ayala (ca. 1530-1615), Garcilaso emplea «al menos cinco capas de un análisis cultural que define el meollo de la enunciación colonial/postcolonial» (Castro-Klarén, 2016, 4). Para una lectura correcta de estas «capas» o niveles de escritura, es importante también tener presente la impronta neoplatónica encontrada en las «fábulas» del Inca (Zanelli, 2016).

5 El trato privilegiado que recibe el padre Acosta en los Comentarios reales no quita que, en el fondo, Garcilaso se opusiera a la consideración peyorativa que el jesuita había proyectado en De Procuranda Indorum Salute (del Pino-Díaz, 2010).

6 La muerte del jesuita Blas Valera fue puesta en discusión por cierta historiografía que lo hizo sobrevivir a un ataque pirata y regresar secretamente al Perú, donde habría escrito la Nueva Corónica y Buen Gobierno, de Guamán Poma de Ayala. Sin embargo, tal hipótesis ha sido categóricamente refutada por diversos especialistas: Adorno, Estenssoro, Guibovich, entre otros (ver, por ejemplo, von Hagen, 2015).
}

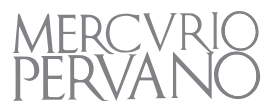




\section{Los Comentarios reales y su función mediadora en los ámbitos cultural y religioso}

Del Inca Garcilaso son incuestionables la contribución a la preservación de la memoria histórica y la calidad literaria de sus escritos. Sin embargo, los académicos han querido destacar su carácter de mediador ${ }^{7}$ puente «entre dos lenguajes, dos culturas: el Antiguo Mundo y el Nuevo Mundo» (Zamora, 1988, p. 59). De ahí su empeño en presentar estas dos realidades como una sola e indivisible entidad, pues «no hay más que un mundo. Y aunque llamamos «mundo viejo» $\mathrm{y}$ «mundo nuevo» es por haberse descubierto aquel nuevamente para nosotros, y no porque sean dos, sino todo uno» (CR, lib. I, cap. I, p. 19). ${ }^{8}$ Por eso, aunque se vista y se alimente, rece, lea y escriba como un español renacentista (Durand, 1963), ${ }^{9}$ el Inca posee un alma genuinamente mestiza, de la que se gloría:

A los hijos de español y de india -o de indio y española-, nos llaman mestizos, por decir que somos mezclados de ambas naciones. Fue impuesto por los primeros españoles que tuvieron hijos en Indias. Y por ser nombre impuesto por nuestros padres y por su significación me lo llamo yo a boca llena, y me honro con él (CR, lib. IX, cap. XXXI, p. 32). ${ }^{10}$

Incluso si se pudiera considerar mestizo al citado Pedro Gutiérrez de Santa Clara, la distancia entre este y el Inca seguiría siendo la misma: la mentalidad del cronista mexicano se correspondía con un alma española incapaz de apreciar la valía de lo autóctono (Porras, 1996, p. 55). En cambio, el prosista cuzqueño quiso anteponer a los antropónimos de su padre Sebastián Garcilaso de la Vega y Vargas, el topónimo de su madre, Chimpu Ocllo, «la Palla doña Isabel [que] fue hija del Inga Gualpa Topac, uno de los hijos de Topac Inga Yupa[n]gui y de la Palla Mama Ocllo, su legitima muger, padres de Guayna Capac Inga, ultimo Rey q[ue] fue del Piru» (Garcilaso de la Vega, 1590, pp. 5-6). Privilegiando su identidad americana, el Inca se reinventó a sí mismo: retomando la esencia de la historia incaica, el discurso de los Comentarios reales aportó como una de sus novedades más significativas la reconciliación fecunda «de las dos razas, la conquistadora y la indígena» (Mariátegui, 2007, p. 198).

\footnotetext{
7 La identificación del Inca como mediador entre culturas se adeuda a S. Gruzinski (2012), punto de referencia en el análisis histórico del proceso de mestizaje americano. Sobre este tema, véase también J. W. Fuerst, 2000, 108. Cabe acotar que calificar a alguien como «mestizo» podría tener actualmente una connotación negativa debido a la carga histórica de violencia presente en tal término (Castro-Klarén, 2016, p. 15).

8 Garcilaso cavila sobre temas arcaicos, superados a inicios del siglo XVII. Sin embargo, su marco argumentativo ha sido justificado: «Garcilaso sitúa la cuestión de la unidad del mundo en un contexto histórico, antes que geográfico o cosmográfico» (Zamora, 1988, p. 166).

9 Sobre la relación del Inca con los humanistas de Andalucía, véase: F. del Pino (2014).

10 Rodríguez Garrido ha puesto en evidencia que esta es la única vez que el Inca Garcilaso se llama y se define a sí mismo como mestizo (Rodríguez, 1995, p. 381).
} 
Efectivamente, la mayoría de los estudios contemporáneos destacan que el cuzqueño pudo reconciliar sus dos genealogías, sin ver en ello «minusvalía alguna ni desde el punto de vista racial, ni religioso, ni cultural» (Vargas, 2016, p. 13). Por esta razón, el Inca ha sido considerado como «el primer «peruano», si entendemos la «peruanidad» como una formación social determinada por la conquista y colonización españolas» (Mariátegui, 2007, p. 198). Chang-Rodríguez corrobora esta tesis mariateguista:

El Inca fue un nuevo sujeto social: un mestizo de la sociedad de la post-conquista [...]; un agudo crítico del coloniaje cuyas funestas consecuencias señaló, pero cuya realidad aceptó. En suma, el luminar cuzqueño fue un ser moderno en sus contradicciones; vivió en un mundo trasatlántico, alternando geografías, linajes, lenguas y culturas (Chang-Rodríguez, 2010a, p. 11).

Este carácter identificatorio ambivalente de la biografía del Inca informa también su obra. Garcilaso redactó los Comentarios reales sobre un soporte de palimpsesto, pues su narrativa trasluce algunos elementos de la historiografía clásica. Así, desde el inicio, el Inca quiso comparar a su subyugada ciudad natal con la Roma subyugante de antaño. ${ }^{11}$ En su ideario, Cusco era la «cabeza de los reinos y provincias del Perú» (CR, lib. VII, cap. VIII, p. 366), relegando a un papel secundario a Lima, la Ciudad de los Reyes. ${ }^{12}$ Esto último, entre otros factores, tuvo un peso decisivo para que se haya afirmado que los Comentarios reales probablemente sea el único libro «en que verdaderamente ha quedado un reflejo del alma de las razas vencidas» (Menéndez-Pelayo, 2008, p. 75). No obstante, esta genuinidad de fondo es expresada formalmente a través de un texto heterogéneo, «compuesto por voces disonantes, y formado por capas de historias, cantos y representaciones, y, empero, simultáneamente influenciado por la clase letrada colonizadora» (Nauss, 2005, p. 11).

A la hora de abordar algunos argumentos sobre los que antes habían cavilado los filósofos clásicos, ${ }^{13}$ Garcilaso advertirá con humildad: «No es este mi principal intento ni las fuerzas de un indio pueden presumir tanto» (CR, lib. I, cap. I, p. 19). Más allá de lo que pueda haber de típica captatio benevolentiae en la fórmula, Garcilaso reiterará esta disculpa antes de emprender la descripción del incario: «Al discreto lector suplico reciba mi ánimo, que es de darle gusto y contento, aunque las fuerzas ni la habilidad de un indio, nacido entre los indios

\footnotetext{
11 Se presenta el Inca «como natural de la ciudad del Cuzco (que fue otra Roma en aquel Imperio)» (CR, «Proemio al lector», p. 16). Garcilaso reforzará el símil entre su ciudad natal y Roma en CR, cap. XX, lib. VI.

12 El Virreinato del Perú se organizó en 1542 y hasta el siglo XVIII mantuvo una enorme jurisdicción que abarcaba todos los territorios españoles en América del Sur, donde el virrey gozaba de una investidura plenipotenciaria.

13 Ya Gonzalo Fernández de Oviedo, primer cronista oficial de las Indias, había recurrido a la historiografía clásica de los griegos y romanos para dotar a sus crónicas de un sentido trascendente (Myers, 2007).
} 
y criado entre armas y caballos, no puedan llegar allá» (CR, lib. I, cap. XIX, p. 55). No existe en el cuzqueño un acomplejamiento autoconmiserativo en razón de su origen ${ }^{14}$. Prueba de ello es que el Inca optó por describir a su linaje materno a través de un estilo solemne: a través de sus páginas, los incas, a pesar de haber sido conquistados, no dejarían de ser un «riquísimo y gran imperio» (CR, lib. I, cap. IV, p. 25). Además, tampoco ocultó su pesar por la destrucción del incario antes de que se hubiese dado a conocer al mundo entero (CR, lib. I, cap. XIX, p. 55).

Para un hombre de letras, el ser hijo de madre inca pudo haberse convertido en un obstáculo (Sobre la situación social de las primeras generaciones de élites mestizas, véase: van Deusen, 2001), pero Garcilaso logró liberarse del estigma social sacando provecho de sus orígenes -he aquí una de las hazañas mejor logradas del Inca-, basando en ello la legitimidad de su historia: «Yo escribo, como otras veces he dicho, lo que mamé en la leche y vi y oí a mis mayores» (CR, lib. III, cap. XXI, p. 173). Este énfasis reiterativo en lo orgulloso que se siente por su linaje materno, no podría interpretarse, por otra parte, como reniego del tronco paterno. De hecho, la relación entre padre e hijo parece haberse caracterizado por un sentimiento de estima mutua. El afecto del capitán Sebastián Garcilaso hacia su vástago mestizo quedará en evidencia, por ejemplo, a través de la pequeña fortuna que le heredará: «porque así es mi voluntad por el amor que le tengo, por ser como es mi hijo natural y por tal le nombro y declaro» (González, 1990, p. 27).

La consideración de estas palabras finales del capitán Garcilaso es particularmente importante: el Inca cargará toda su vida con el peso de ser hijo natural y no legítimo; mácula moral y, por tanto, social en un medio obsesionado por la pureza de sangre (Guardia, 2013). Máxime cuando, presionado por la Corona, el conquistador tomó por esposa a una doncella española, originando que «Isabel Chimpu Ocllo, la madre de Garcilaso, fuera forzada a desposarse con Juan del Pedroche, un plebeyo español» (Chang-Rodríguez, 2006, p. 17). Tales sucesos no quedaron registrados en las páginas de los Comentarios reales; un silencio elocuente del que se podría colegir la ignominia que pudo haber experimentado el Inca.

En 1560, un año después del fallecimiento de su padre, Gómez Suárez se embarcó hacia la península ibérica despidiéndose para siempre de la tierra americana (Chang-Rodríguez, 2010b). Garcilaso cruzó el Atlántico con el objetivo de reclamar un resarcimiento económico por los servicios militares de su padre, así

\footnotetext{
14 Marta del Pozo ha señalado el carácter ambiguo del discurso garcilasista. Tratando de encontrar los motivos por los cuales el Inca decidió traducir del italiano al español los Diálogos de amor de León Hebreo, «trampolín del Inca en el mundo literario», ha afirmado: «Quizás al rescatar la obra de un judío exiliado de España en el siglo de las persecuciones, el Inca buscase lograr una mayor tolerancia hacia la hibridez y el sincretismo cultural de la que la Península Ibérica había sido testigo por tantos siglos» (Del Pozo, 2012, p. 5).
} 
como para pedir la restitución patrimonial de su madre. Una vez hubo desembarcado en tierra paterna, se instaló en Montilla, acogiéndose bajo los auspicios de su tío Alonso de Vargas, que lo adoptó pródigamente (Bernand, 2009). No transcurriría mucho tiempo para que el cuzqueño emprendiera el deseado viaje a Madrid, donde Felipe II había trasladado su Corte. Sin embargo, el fracaso fue rotundo: su petitorio fue rechazado clamorosamente y la memoria de su padre fue denigrada, acusándosele de haber colaborado con el rebelde Gonzalo Pizarro (Rodríguez, 2016):

La frase de quien había levantado el falso testimonio contra su padre, Lope García de Castro - «lo que está escrito por los historiadores no puede negarse»-, debió de convertirse en un buen revulsivo para la elaboración de sus Comentarios reales: corregir a los cronistas y restituir la verdad, historiarla y hacerla respetable por la autoridad que confiere la palabra escrita (Serna, 2000, p. 15).

Algunos estudiosos han querido ver en la humillación que le fuera infligida en la Corte (E. Garramiola, 1993, p. 102), el motivo principal para que, a partir de aquel suceso, Gómez Suárez empezara a firmar como «el Ynca Garcilasso de la Vega». ${ }^{15}$ Lo cierto es que, aunque no se pueda seguir el rastro a muchos pasajes de su vida, el cuzqueño se granjeó entre sus coetáneos una estimable reputación, tanto en la villa de Montilla, desde su llegada en 1560, ${ }^{16}$ como en la ciudad de Córdoba, desde 1591 hasta su muerte. Para fundamentar lo anterior, baste recordar que el Inca ocupó durante algún tiempo el cargo de procurador en Montilla; que se le dedicó una obra lingüística y que se le citó en otras tantas; y que apadrinase un buen número de bautismos. Más aún -tal vez el hecho más revelador- es importante tener presente que en 1579 el Inca Garcilaso recibió las órdenes menores; hecho que presuponía, amén de conocer la lengua latina, el contar con «informes positivos de personas fidedignas» (Vergara, 2005, p. 108).

\section{El credo católico como clave hermenéutica de los Comentarios reales}

Los rasgos biográficos señalados precedentemente no han sido gratuitos: Los Comentarios reales proyectan, de alguna manera, el rumbo que tomó la vida de su redactor. Garcilaso fue uno de los casos «en que la comprensión cabal de

\footnotetext{
15 Se ha señalado que el Inca habría sufrido un fuerte conflicto de identidad que se manifestó, precisamente, «a través de los constantes cambios de nombre que, sin duda, muestran una incansable búsqueda de identidad llevada a cabo por el mestizo peruano en el discurso narrativo de los Comentarios reales» (Fernández, 2004, p. 59). Para un estudio sintético de los nombres adoptados por el Inca, véase F. de Solano, 1991. sobre las motivaciones que habría tenido Garcilaso para asumir el título de «Inca», véase: Duviols (2005).

16 Treinta años en Montilla «que fueron de meditación fecunda y feliz aprendizaje de sosiego» (Porras Barrenechea, 1950, p. 15).
} 
la obra de un autor pasa necesariamente por el conocimiento adecuado de su vida» (Cornejo, 2000, p. 19). La obra es la celebración de las dos caras de la misma medalla mestiza que se acuñó bajo el Virreinato del Perú y siguió prolongando su coexistencia bajo el régimen republicano: «las dos realidades que forjan la identidad del Perú como país, la inca y la española, se hacen tan profundamente inseparables la una de la otra que, desde aquel tiempo, la una no ha podido vivir sin la otra» (MacCormack, 2007, p. 67). No obstante, a través de la historia, esta inseparabilidad entre los elementos autóctonos y foráneos no ha supuesto necesariamente una integración siempre armónica (Méndez, 1996).

Tiempo turbulento, estriado por espadas, el que le tocó vivir al Inca. En 1659, él mismo tomó parte en la lucha contra el sublevamiento morisco en Granada. Posteriormente, se unió a la mesnada del Marqués de Priego en una nueva edición de aquella centenaria lucha político-religiosa. Símil antojadizo: Cervantes batalló contra los musulmanes en Lepanto; Garcilaso hizo lo propio en las Alpujarras, consiguiendo el título de Capitán de Su Majestad. Sin embargo, ambos sabían que, a pesar de las guerras hemorrágicas de aquel tiempo, no había arma más potente que la pluma: «En el siglo XVI se libraron batallas feroces para controlar el pasado: la historia sirvió como un arsenal ideológico que proveía de argumentos y de hechos para justificar derechos e intereses políticos presentes» (Brading, 1986, p. 1).

En este contexto, no resultaba extraño que muchos escritores tuvieran que fungir muchas veces de historiadores, improvisando la fabricación literaria de hechos pasados, plagiando textos, maquillando errores, magnificando hechos más bien ordinarios; extremamente solicitados por quienes detentaban el poder para fabricar un pasado que confiriera cierta aura moralizadora a sus acciones en el presente: cualquier mensaje escrito podía adquirir un estatus de talismán (Araujo, 2007). Por ello, el Inca Garcilaso se preocupó, una vez más, por dejar en claro que si escribía lo hacía amparado en fuentes del todo atendibles: «para que no digan que finjo fábulas a favor de la patria y de los parientes» (CR, lib. V, cap. VI, p. 230).

La celebridad le llegó al Inca en el ocaso de su vida: recién en 1609, contando Garcilaso setenta años, se publicó en Lisboa la primera edición de los Comentarios reales. Ante la imposibilidad de retornar físicamente a la patria americana, sus pensamientos sobrevolaron el Atlántico; y el corazón le oxigenó la mente para que brotaran, a borbollones, los recuerdos del incario. El Inca se sirvió de un género nuevo en el cual se fundían la intimidad biográfica, el enfoque histórico y la audacia reflexiva, alterando así «la teoría misma de los géneros» (Neira, 2009, pp. 149-150).

Por esta razón, no son infrecuentes en los Comentarios las descripciones coloridas y las anécdotas enganchadoras, digresiones que obsequian a la obra un marco literario digno. En este sentido, la narración del naufragio de Pedro Serrano es ejemplar. Garcilaso dedicó varias páginas para contar cómo este náu- 
frago español se las tuvo que agenciar para sobrevivir en una isla desierta: desde el reto diario de conseguir con qué alimentarse, hasta la descripción de su choza, construida ingeniosamente con los caparazones de tortugas gigantes. ${ }^{17}$ Finalmente, al cabo de tres años, la soledad de Serrano se vio interrumpida por el arribo de otro desafortunado:

Serrano imaginó que era el demonio que venía en figura de hombre para tentarle en alguna desesperación. El huésped entendió que Serrano era el demonio en su propia figura, según lo vio cubierto de cabellos, barbas y pelaje. Cada uno huyó del otro, y Pedro Serrano fue diciendo: «jJesús, Jesús! ¡líbrame, Señor, del demonio!». Oyendo esto se aseguró el otro, y volviendo a él le dijo: «No huyáis, hermano, de mí, que soy cristiano como vos». Y para que se certificase, porque todavía huía, dijo a voces el Credo. Lo cual oído por Pedro Serrano volvió a él y se abrazaron con grandísima ternura y muchas lágrimas y gemidos, viéndose ambos en una misma desventura, sin esperanza de salir de ella (CR, lib. I, cap. VIII, p. 34).

Es interesante resaltar una clave exegética que podría correr el riesgo de naufragar en el maremágnum de los Comentarios reales: el credo. Sin ánimo de destripar el desenlace de la historia, los náufragos no perecerán en la isla; a la sazón, estos serán rescatados. Garcilaso describió pintorescamente que la apariencia física de los náufragos se había deteriorado y afeado de tal modo que no tenían ya «figura de hombres humanos» (CR, lib. I, cap. VIII, p. 35). Al verlos deshumanizados, el grupo de marineros del navío que providencialmente acudió en su rescate, se alarmó y, si no hubiese sido porque estos empezaron a jesusear y a decir el credo en voz alta, hubiera abandonado a su suerte a los náufragos. En otras palabras, Serrano y su compañero se salvaron por haber mostrado sus credenciales católicas. No se trata de una casualidad: las narraciones en clave providencialista constituyen el fil rouge del discurso redentor del Inca.

Los Comentarios reales se convierten, entonces, en un poderoso radiorreceptor que recoge y transforma en señales cristianas las ondas transmitidas por sus propias fuentes incaicas. Hemos dicho antes que el alma de Garcilaso es mestiza, pero tan genuino es su mestizaje cuanto lo es su fe cristiana. En otras palabras, el sustrato de sus páginas hunde sus raíces en sus creencias religiosas: «Era un cristiano convicto y confeso que no veía con odio y desprecio la religión de sus ancestros incas, sino con un respeto que también es extraordinariamente avanzado para su tiempo» (Vargas, 2010b, p. 194). Esta es la patente de corso que compele al Inca a asumir lo que él considera como una misión profética; vale decir: anunciar y denunciar, directa e indirectamente, el pisoteo cainita de

17 Es interesante analizar cómo, a lo largo de los Comentarios reales, Garcilaso desafía el imaginario tradicional con representaciones de europeos salvajes e indios civilizados, a través de una constante inversión de paradigmas (Heid, 1997).

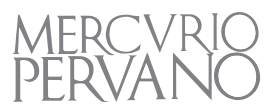


los españoles peninsulares hacia sus hermanos americanos en nombre de Dios. El Inca no quiso barnizar la religión de sus antepasados maternos, sino que la conminó, la conjuró y la exorcizó. No hay contradicción entre estos dos anhelos profundos: la tinta del Inca fluyó para sentar las bases historiográficas «de un Sacro Imperio Inca, con una clase mestiza noble gobernando un reino cristiano construido sobre fundamentos indígenas» (Brading, 1986, p. 23).

A medida que los Comentarios reales fueron obteniendo una acogida favorable en los círculos intelectuales, a los ojos de la Corona la narrativa del Inca se fue descubriendo subversiva $y$, por tanto, contraria a sus intereses reales. Por ello, aunque tardíamente, su lectura entró en el Índice: el Inca no fue la excepción: «la actitud de «sospecha» [era] frecuente en el gobierno y la administración española» (Oviedo, 2010, 150). Junto con su fuerte contenido religioso, el texto de del cuzqueño repercutía también en temas políticos, sociales y económicos (Ward, 2010). No se podía tolerar la presentación del incario como una communitas perfecta en la que las necesidades básicas se encontraban satisfechas al punto que «nadie podía llamarse pobre ni pedir limosna; porque lo uno y lo otro tenían bastantemente, como si fueran ricos» (CR, lib. V, cap. IX, p. 234). Esta utopía era potencialmente inflamable ante los nuevos vientos políticos que corrían por Europa y en medio de un contexto de pauperización social.

Garcilaso no fue indiferente ante el dolor humano; antes bien, sus páginas transmiten un alto nivel de empatía ante la pobreza de sus hermanos americanos: « $i Y$ con ser la tierra tan rica y abundante de oro y plata y piedras preciosas, como todo el mundo sabe, los naturales de ella son la gente más pobre y mísera que hay en el universo!» (CR, lib. VIII, cap. XXIV, p. 471). El pasado glorioso y el presente arruinado del imperio incaico en la versión utópica de Garcilaso podía ser interpretado como una interpelación a la Corona española que, ante el pensamiento de buena parte de sus súbditos, se había enriquecido con las remesas constantes de metales preciosos de sus dominios americanos a expensas del encarecimiento de los productos básicos (Fischer, 2018). Así pues, en muchos pasajes de los Comentarios reales subyace la capacidad interpelante de su autor que demostró ser un hombre juicioso: interpela, respetando los límites; sugiere los problemas de fondo, sin ser escandalosamente explícito; es valiente, sin llegar a ser temerario.

Garcilaso no reprimió su pluma: la desató para dejarla ser explícita. No resulta extraño, entonces, que en su relato sobre la fundación del Cusco, se deshiciera en epítetos por Manco Cápac y Mama Ocllo Huaco, hijos del Sol y de la Luna, y que cuando terminó de narrar sus hazañas, pusiera en la voz de su fuente -el Inca anónimo, tío de su madre- palabras denunciatorias: «Y por no hacerte llorar no he recitado esta historia con lágrimas de sangre derramadas por los ojos, como las derramo en el corazón del dolor que siento de ver nuestros incas acabados y nuestro imperio perdido» (CR, lib. I, cap. XVII, p. 50). Acaso 
su fuente no sea sino un alter ego del autor que le presta su voz para escamotear cualquier viento inquisidor a través de una magistral coartada literaria. Este tipo de narraciones que mostraban un rostro afable de la América española debieron haber sido leídas con recelo e inquietud durante el régimen de Felipe III (Araníbar, 2009).

Los inicios del siglo XVII supusieron un punto de inflexión para la monarquía española: tuvo que asimilar el relevo regio, asumir la bancarrota del tesoro real, convalecer de la peste que había diezmado a su pueblo y evitar el desborde de las clases más desfavorecidas en pleno hervor social. Y, al mismo tiempo, dicha monarquía, a pesar de su hegemonía previsiblemente decadente, tenía la conciencia de seguir reinando sobre la primera potencia mundial. Por ello, a pesar del impacto que la difusión de los Comentarios reales tuvo en el imaginario popular, en la península ibérica solo se publicaron dos ediciones en los primeros dos siglos. En cambio (Guibovich, 2016), la proyección extrapeninsular de la obra fue notabilísima: sirvió como caldo de cultivo en la Francia revolucionaria y se empleó también en los discursos peruanos filoindependentistas. ${ }^{18} \mathrm{En}$ la historia político-intelectual europea y latinoamericana, los Comentarios reales tuvieron indudablemente un impacto profundo..$^{19}$ Por este motivo, la obra ha sido estudiada en diversos tiempos y con múltiples propósitos, bajo el quirófano de las ciencias histórico-sociales: ${ }^{20}$

Ningún libro sobre las civilizaciones indígenas americanas, excepto la Brevísima relación de la destrucción de las Indias del padre Las Casas, gozó de un éxito tan rotundo como los Comentarios reales. Durante más de cuatro siglos la imagen de los Incas será aquella que Garcilaso forjó en su obra (Bernand, 2009, pp. 12-13).

\section{El exitoso injerto histórico de un imperio pagano en un tronco cristiano}

La técnica de filigrana empleada por el Inca en la redacción de sus Comentarios reproduce los recursos propios del ambiente renacentista y es fruto de su amplia cultura humanística. ${ }^{21}$ Sin embargo, el cuzqueño no escribió para falsear

\footnotetext{
18 La primera traducción de la obra estuvo a cargo de Jean Baudoin; esta sirvió como «base de al menos cuatro reediciones antes de que en 1744 Thomas François Dalibard realice una nueva -e innovadora- versión de la obra» (Macchi, 2009, p. 96).

19 Se ha hecho notar la instrumentalización de las obras del Inca Garcilaso en los siglos XIX y XX; así como las polémicas defensas de su obra (Cortez, 2018).

20 La obra ha sido objeto de diversos estudios historicistas, ideológicos, filológicos y colonialistas (Huamán, 2009).

${ }_{21}$ La amplitud de su cultura renacentista puede ser corroborada a través del inventario de su biblioteca. Véase: Durand (1948) y Hampe (1994). A los pocos días de la muerte del Inca, sus albaceas testamentarios inventariaron 188 entradas, confirmando «un humanismo al día y de profunda raigambre» (López, Ortiz y Firbas, 2016, p. 23).
}

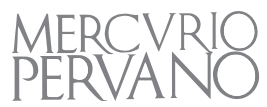


la realidad: sus inexactitudes, sus licencias literarias, sus eclosiones poéticas y sus excusas hiperbólicas obedecen a un sometimiento religioso (Silva, 2010). La pluma de Garcilaso rasga las páginas de la historia para inyectar en ellas tinta cristiana. Los Comentarios se convierten, así, en trozos de memoria unidos por la necesidad reivindicativa de su autor de insertar la historia de sus ancestros en el plan salvífico de la divina Providencia (Amaya, 2016). En efecto, «el trasfondo de los Comentarios reales no es ajeno a toda una amplia tradición concordista cristiana que, según su naturaleza, es providencialista» (Eguiguren, 2016, p. 50). Según este enfoque, el incanato trazó la línea divisoria temporal y soteriológica del Nuevo Mundo. ${ }^{22}$

A través de este peculiar enfoque teológico adoptado por el Inca (Millones, 2010), los incas son a la religión cristiana lo que los antiguos profetas de Israel fueron para Jesucristo: precursores del Mesías. De allí que los Comentarios reales transmitan también una cosmogonía que, para no ser infravalorada por sus lectores europeos, fue engrapada por su autor a las páginas de la biblia. Así, por ejemplo, al dar cuenta del origen de los reyes incas, Garcilaso hizo referencia a un diluvio universal, insinuando que se habría tratado de la misma inundación que había cubierto la tierra en tiempos de Noé (CR, lib. I, cap. XVIII, p. 52). Este afán «concordista», en su intento por anclar la génesis del incario al Génesis bíblico, puede ser considerado como un programa de reivindicación religiosa; lo cual acarreaba también una legitimización regia con consecuencias políticas imprevisibles (Rodríguez, 1995).

Se ha dicho ya que el estilo garcilasista no fue ajeno a los cánones de la historiografía renacentista; sin embargo, habría que añadir que esta tendía a dividir la historia en edades (Burckhardt, 1860). ${ }^{23} \mathrm{El}$ Inca no se sustrajo a esta tendencia y propuso una división tripartita de la historia andina «para fundamentar una concepción según la cual la historia sigue progresivamente y es conducida por la providencia de Dios» (Amaya, 2016, p. 39). En la Primera Edad florecieron los reinos de la antigua gentilidad, sumidos en la idolatría (CR, lib. I, cap. X, p. 37); estos, «conforme a la vileza y bajeza de sus dioses» les ofrecían sacrificios humanos (CR, lib. I, cap. XI, p. 38). La Segunda Edad, principiada por Manco Cápac, correspondió al dominio monárquico incaico, cuyo apogeo se dio bajo el reinado del inca Pachacútec y cuyo ciclo se cerró con la muerte de Túpac Amaru,

\footnotetext{
22 Sobre la cuestión religiosa como elemento subyacente en los escritos garcilasistas, destaca la obra de Pierre Duviols, quien ha dedicado más de sesenta años de fructuosa investigación histórica sobre la vida y la obra del Inca Garcilaso. Véase, por ejemplo: Duviols (1958), (1964), (1988).

23 El término en cuestión es de acuñación tardía; se difundió a partir de la publicación de La civilización del Renacimiento en Italia, de Burckhardt. El historiador suizo se sirvió de dicho término para delimitar el período comprendido entre el Medioevo y la Edad Moderna (Burckhardt, 1860). Se tiende a asignar al Renacimiento tres siglos de duración, computados a partir de 1350 (King, 1991).
} 
el último monarca incaico. ${ }^{24}$ Según el cronista cuzqueño, durante este período los incas se convirtieron en instrumentos de la mano providente de Dios para iluminar con la luz de sus virtudes las oscuras tinieblas que los precedieron ${ }^{25}$. Finalmente, la Tercera Edad se inauguró cuando los incas dieron por concluida su misión de urbanizar a los bárbaros, preparando así el terreno para el anuncio fecundo del evangelio:

Para que cuando ese mismo Dios, Sol de justicia, tuviese por bien de enviar la luz de sus divinos rayos a aquellos idólatras, los hallase, no tan salvajes, sino más dóciles para recibir la fe católica y la enseñanza y doctrina de nuestra santa madre Iglesia romana (CR, lib. I, cap. XV, p. 45).

La cita precedente posee una particular importancia por tres razones. En primer lugar, la presentación de Dios como el «Sol de justicia» no puede considerarse gratuita. ${ }^{26}$ Como se sabe, los incas tuvieron «al sol por dios visible, a quien ofrecieron sacrificios e hicieron grandes fiestas» (CR, lib. II, cap. II, p. 70). En segundo lugar, Garcilaso tuvo cuidado en separar a los pueblos idólatras de los incas. A estos últimos los absolvió de actos idolátricos no solamente por aquella especie de labor catequética que llevaron a cabo en favor de los pueblos precedentes, sino también porque sus antepasados maternos adoraban, aunque no lo supieran, a un «dios no conocido» (CR, lib. II, cap. II, p. 71). Esta referencia debe leerse a la luz de uno de los discursos más memorables de san Pablo en el Areópago. El Apóstol, elogiando premeditadamente la religiosidad de los atenienses, quiso justificar su presencia en medio de ellos: «He encontrado un altar en el que estaba grabada esta inscripción: «Al Dios desconocido». Pues bien, lo que adoráis sin conocer, eso os vengo yo a anunciar» (Hch 17, 22-23). En otras palabras, los incas, al igual que los atenienses, habían estado adorando (que no idolatrando) a un Dios ignoto (P. Duviols, 1994). Es más, los incas tuvieron aún mayor mérito al haber rastreado «con lumbre natural al verdadero sumo Dios y señor nuestro que creó el cielo y la tierra» (CR, lib. II, cap. II, p. 70). ${ }^{27}$ Por último, Garcilaso quiso indicar que el culmen del itinerario religioso incaico se alcanzaría con la recepción de la fe católica cuya doctrina seguía siendo transmitida por la Iglesia de Roma. Según el Inca, el tiempo propicio, la plenitud de los tiempos, había llegado (cf. 2 Cor 6,2; Gal 4,4).

En los Comentarios reales, los incas fueron asemejados a los israelitas antes de la llegada del Mesías que habría de otorgarles la salud. En el imperio incaico también se ofrecía holocaustos a su dios, el Sol, consagrándole los bienes más preciados. Al advertir que, a diferencia de los bárbaros preincaicos, sus ances-

\footnotetext{
24 El fin del incanato concluye en el libro VIII de la segunda parte de los Comentarios reales, que conforma una unidad del relato dinástico (Mazzotti, 1996).

25 Se trata de la praeparatio evangelica. Sobre este punto, véase: Martínez-San Miguel (2008).

$26 \mathrm{Al}$ respecto, las referencias bíblicas son abundantes; véase, por ejemplo, Mal 4,2 y Lc 1,78.

27 Algunos autores han considerado que Garcilaso hace referencia a Pachacámac para reivindicar el nivel intelectual y religioso de los incas (Parra, 2014).
} 
tros no habían ofrecido seres humanos como víctimas de propiciación, el Inca apologizaba sutilmente en favor de su pueblo materno.

Según Garcilaso, el incario tuvo buenos gobernantes, mejores legisladores y óptimos administradores, solidarios con los pobres (CR, lib. II, cap. XV, p. 100; lib. V, cap. II, p. 222). Para argumentar su tesis, el cuzqueño ponderó la prudencia y gallardía de Sinchi Roca (CR, lib. II, cap. XVI, pp. 102-104); y no fue menos generoso con Lloque Yupanqui, su sucesor, de quien afirmó que reunía en sí «todas las virtudes que un rey bueno puede tener» (CR, lib. II, cap. XVII, p. 104). Dedicó, además, seis capítulos para enaltecer los logros incaicos en los diversos campos de la ciencia (astrología, medicina, geometría, geografía y aritmética) (CR, lib. II, caps. XXI-XXVI, pp. 111-122) ${ }^{28}$. Y, aunque el Inca había escrito antes que «toda comparación es odiosa» (CR, lib. I, cap. XIX, p. 55), su mensaje se infiere con claridad meridiana: había evidencias para no considerar a la civilización incaica como inferior a la europea.

En el libro tercero de los Comentarios reales Garcilaso quiso sintetizar los hechos épicos obrados por Mayta Cápac, un Inca lento a la ira y compasivo (Jl 2,13). El perfil epopéyico de Cápac Yupanqui se asemejaba al de su antecesor en términos marciales, pero Garcilaso añadió a su relato un tono parenético. Así, cuando el general Auqui Titu refirió a Cápac Yupanqui lo que había podido apreciar de los pobladores de los valles costeños que había sometido, hizo énfasis en que estos idolatraban a dioses marinos que luego consumían en sus alimentos, y que se había percatado que tenían costumbres sodomíticas ${ }^{29}$. A Cápac Yupanqui pareció no importarle aquella especie de deicidio perpetrado por sus nuevos súbditos; pero sí le indignó lo que consideraba como una inmoralidad sexual. Para remediar esto último, su respuesta fue draconiana y ejecutó un terrorífico plan disuasorio. No solamente hizo quemar vivos a los que fueron hallados culpables, sino también a los indiciados; mandó a quemar sus casas y arrancar de raíz los árboles de sus campos: «so pena de que por el pecado de uno sería asolado todo su pueblo y quemados sus moradores en general, como entonces lo eran en particular» (CR, lib. III, cap. XIII, p. 154).

\footnotetext{
28 Los incas contaron también con amautas-filósofos que abogaban por la virtud del imperio y con músicos y harauicus-poetas que cantaban sus gestas (CR, lib. II, cap. XXVII, pp. 122-126). 29 El mismo «abominable vicio de la sodomía» sería combatido en la provincia de Huaylas (CR, lib. VI, cap. XI, p. 300). El Inca Garcilaso cita a Pedro de Cieza de León para presentar una narración más explayada y explícita de la sodomía. En efecto, refiere que los «gigantes» de la punta de Santa Elena, a falta de mujeres que «les cuadrasen por su grandeza», practicaron relaciones homosexuales. Esta acción los hizo acreedores del castigo divino: «Vino fuego del cielo temeroso y muy espantable haciendo gran ruido, del medio del cual salió un ángel resplandeciente con una espada tajante y muy refulgente, con la cual de un solo golpe los mató a todos. Y el fuego los consumió, que no quedó sino algunos huesos y calaveras, que para memoria del castigo quiso Dios que quedasen sin ser consumidos del fuego» (CR, lib. IX, cap. IX, p. 492).
} 


\section{Las correspondencias bíblicas en los Comentarios reales}

A través del caleidoscopio cristiano de los Comentarios reales, la ciudad de Cusco fue asimilada a la Jerusalén veterotestamentaria. Por consiguiente, el Coricancha, el templo del Sol, no debía ser menos suntuoso que su par jerosolimitano. Y así lo describió: un altar orientado según una antojadiza coincidencia con la tradición judeo-cristiana; paredes recubiertas con planchas de oro y una representación descomunal de la divinidad solar entronizada en una especie de sancta sanctórum del recinto religioso: «Fueron tan increíbles las grandezas de aquella casa que no me atreviera yo a escribirlas» (CR, lib. III, cap. XX, p. 170).

Dotados de tal templo, los incas tuvieron también un sumo sacerdote, pontífice andino, que cantaba los sacrificios, interpretaba sueños y gozaba de un canal de comunicación privilegiado con la divinidad cuyos designios transmitía luego al pueblo (CR, lib. III, cap. XXII, pp. 173-174). Así pues, el Cusco se convirtió en los Comentarios reales en la Ciudad Santa del Nuevo Mundo, una prefiguración apocalíptica del nuevo cielo y la tierra nueva, «engalanada como una novia ataviada para su esposo» (Ap 21,2). Y, a semejanza de la ciudad bíblica escatológica, en la metrópolis cuzqueña abundaban los jardines de oro y plata. Cuando Garcilaso refirió que en aquellos jardines cohabitaban «muchos animales chicos y grandes, bravos y domésticos» (CR, lib. III, cap. XXIV, p. 177), es probable que estuviese enviando un mensaje subliminal a sus lectores familiarizados con aquella armonía genesíaca profetizada por Isaías: «Serán vecinos el lobo y el cordero, y el leopardo se echará con el cabrito, el novillo y el cachorro pacerán juntos, y un niño pequeño los conducirá» (Is 11,6).

El régimen de Cristiandad europeo, desde el cual el Inca tejió sus recuerdos, fue el humus que favoreció el crecimiento de osados parangones eclesiásticos (Saranyana y Alejos-Grau, 1996). Cuando el joven Gómez Suárez hubo emprendido su viaje al Viejo Mundo, los franciscanos aún no habían terminado de fundar en Cusco los ocho monasterios de clarisas que le aportarían cierta mística franciscana a la capital imperial (Martínez, 1995). En cambio, en la región andaluza en la que se asentó el Inca, florecían a la sazón los claustros contemplativos femeninos al amparo de los Fernández de Córdoba Aguilar, marqueses de Priego (Atienza, 2008). Por eso, no extraña que, en su referencia a las vírgenes dedicadas al Sol, Garcilaso se prestara términos del derecho eclesiástico para señalar «la profesión de perpetua virginidad» de ciertas mujeres que vivían en «casas de recogimiento». ${ }^{30}$ A estas vírgenes el Inca no solamente las designó como «monjas», sino también «sacerdotisas», dependientes de las Mamacuna, que hacen las veces de «abadesas» $\mathrm{y}$ «maestras de novicias». No contento con equiparar el estilo de vida de las vírgenes del Sol con el de las monjas católicas,

\footnotetext{
30 CR, lib. IV, cap. I, p. 182. El Inca Garcilaso remite también al lector a las vestales, reforzando
} así el vínculo de Cusco con Roma (Pease, 1999).

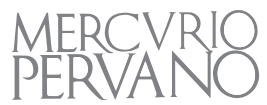


Garcilaso quiso ameritar aún más el rigor de las primeras cuyos monasterios no tenían «locutorio» ni «torno», aminorando el riesgo de que alguien osara verlas; permiso que ni siquiera el inca reinante se dispensaba a sí mismo y cuya licencia cedía solo a la coya, la reina inca, y a sus hijas. La pena para quien infringiera la clausura de estas «escogidas» era gravísima: no solo se quemaría vivo al infractor, sino también a sus hijos, padres, parientes, vecinos, animales y posesiones, salinizando y empedrando sus tierras, como si no hubiese bastado con lo anterior (CR, lib. IV, cap. III, p. 186). De esta manera, el prosista cuzqueño panegirizaba el pudor, la continencia y la castidad incaicas, camuflando en un segundo plano el incesto de los gobernantes andinos (CR, lib. IV, cap. IX, pp. 193-194).

En el estamento religioso del imperio de los antepasados maternos de Garcilaso tampoco se carecía de «sacramentos». Por una parte, el inca era el encargado de presidir, anualmente o cada dos años, los ceremoniales de los «matrimonios» de su linaje; en los demás casos, el inca delegaba sus funciones en «ministros» ad hoc (CR, lib. IV, cap. VIII, pp. 191-192). Por otra parte, la fiesta de la trasquiladura de los niños apenas destetados era un rito que se emparentaba gráficamente con el bautismo católico, pues allí también se les asignaba un nombre y se les escogía padrinos (CR, lib. IV, cap. XI, p. 196). En esta historia ritualizada que presenta el Inca, J.A. Mazzotti ha visto un santiguamiento omnipresente: «las referencias a la cruz en los Comentarios son abundantes y suelen darse en relación con el protocristianismo implícito de los incas» (Mazzotti, 2010, p. 87).

Según refiere Garcilaso, en el imperio incaico se inculcaba en los niños, desde su más tierna edad, el espíritu de sacrificio y abnegación. Las madres no se permitían mimos ni caricias que pudiesen destemplar a sus críos; más bien, se encargaban de espabilarlos mañosamente a través de una pedagogía que, a un tiempo, les despertaba una proactividad prematura y les auguraba un futuro libre de indisciplina, glotonería y desaseo (CR, lib. IV, cap. XII, p. 198). Acaso haya sido esta una manera de acusar indirectamente los vicios de los españoles, cuyas madres, a diferencia de las indias, necesitaban de parteras, tardaban en reponerse del alumbramiento y malcriaban a los recién nacidos. No fue la única comparación de caracteres descrita en los Comentarios reales. También se corrobora la superioridad del talante de las mujeres del Tahuantinsuyo: ellas trabajaban codo a codo con sus pares varones en el campo. Además, las indias eran amigas del hilar y «enemigas de perder cualquier pequeño espacio de tiempo» (CR, lib. IV, cap. XIII, p. 199). No obstante, en la sociedad idealizada de los Comentarios reales, también había lugar para las pampairuna, mujeres que se prostituían «en los campos, en unas malas chozas, cada una de por sí y no juntas». Aborrecidas como parias en el incario, eran toleradas «por evitar mayores daños» (CR, lib. IV, cap. XIV, p. 201).

En la saga gloriosa de los emperadores incas, desde Inca Roca hasta Huayna Cápac, Garcilaso mantuvo el mismo patrón: todos fueron personajes pre- 
destinados, superdotados, intachables moralmente, magnánimos, instrumentos providenciales que extendían los dominios del Tahuantinsuyo y que, no contentos con avasallar a otros pueblos, buscaban convertirlos a su fe casi monoteísta para que abandonasen los ídolos «hechos de piedra y madera» y reconociesen al verdadero Dios (CR, lib. IV, cap. XVII, p. 207). ${ }^{31}$ Sin embargo, como los dioses olímpicos, los reyes incas también fueron seres pasionales. Así, por ejemplo, la falta de carácter del supersticioso Yáhuar Huácac habría propiciado la rebelión de los chancas, habitantes indómitos del Chinchasuyu (Turner, 1988); Viracocha Inca, su hijo, superaba con creces la bravura de su padre, pero su carácter era sumamente explosivo. Es interesante notar cómo Viracocha, a pesar de este defecto, fuese un receptor continuo de una serie de revelaciones divinas que le llegaban a través de un «fantasma» que Garcilaso describió con facciones europeas y rostro barbado (CR, lib. IV, caps. XXI-XXIII, pp. 213-217). Algunas analogías bíblicas podrían hacerse; pero el Inca quiso tomar a san Bartolomé, apóstol, como referente hagiográfico (CR, lib. V, cap. XXII, p. 263).

Al Inca Viracocha, padre de Pachacútec, no solo le fue revelada la advertencia de un ataque inminente de sus enemigos, sino que también se le anticipó la llegada de los españoles, «gente nunca jamás vista» que portarían consigo el antídoto a las idolatrías persistentes aún en los cuatro suyos (CR, lib. V, cap. XXVIII, p. 275). ${ }^{32}$ De esta manera, Viracocha pasaba a personificar una especie de nuevo Balaam, aquel legendario adivino quien fuera sobornado por Balac para maldecir al pueblo de Israel y que, sin embargo, terminaría bendiciéndolo ante la imposibilidad de contrariar el designio de Dios: «He aquí, un pueblo se levanta como leona, y se yergue como león; no se echará hasta que devore la presa y beba la sangre de los que ha matado» (Núm 23,24).

Ambas profecías, la de Balam y la de Viracocha, no tardarían en cumplirse. Garcilaso concluyó el libro quinto atestiguando que, a su paso por Lima, antes de partir a España, pudo ver el cuerpo intacto de Viracocha. El cuzqueño aprovechó esta anécdota para alabar la técnica embalsamadora de los incas, pero quién sabe si en la mente de sus lectores, a ambas orillas del Atlántico -en un medio «con una dependencia extrema del universo sobrenatural»- (Sánchez, 1993, p. 278), no rondaría la idea de reconocer el milagro patente de un cuerpo incorrupto. ¿Sería osado afirmar que el Inca hubiese intentado canonizar a Viracocha, uno de los miembros más insignes de su linaje? Lo cierto es que las referencias constantes a sacramentos y sacramentales, capillas y templos, sumos sacerdotes y vírgenes perpetuas, sacrificios y holocaustos, ceremoniales y ayunos, revelaciones y profecías mesiánicas son elementos que, a través de una

\footnotetext{
31 Véase la correspondencia con Dt 4,28; Lv 26,1; Hab 2,18; etc.

32 Algunos estudiosos han leído esta atribución a Viracocha de la victoria sobre el pueblo chanca con el propósito de «disminuir la disminuir de Pachacútec», dado que la familia del Inca Garcilaso pertenecía al linaje real iniciado por dicho inca (Rostworowski, 1999, p. 167).
} 
lectura extrapolada de los Comentarios reales, conducen inequívocamente a las fuentes bíblicas de las que bebe su autor.

Garcilaso coronó su monumento protocristiano desenvolviendo todo un calendario litúrgico-agrícola inca, con cuatro fiestas principales, que gravitaban en torno al Inti Raymi, la Pascua del Sol, «en reconocimiento por tenerle y adorarle por sumo, solo y universal Dios» (CR, lib. VI, cap. XX, p. 315). ${ }^{33}$ la maquinaria propia de los festivales y su parafernalia, incluyendo la teatralización de los curacas vestidos de ángeles y demás seres carnavalescos. Con su habitual enfoque concordista, el Inca quiso narrar cómo en el Inti Raymi, al igual que en la Pascua mosaica, se sacrificaba un cordero prieto, sin mancha ni defecto (CR, lib. VI, cap. XXI, pp. 318-319). Una vez más, el camino para la aceptación de Cristo, el Cordero degollado, había quedado magistralmente allanado en las páginas del Inca Garcilaso.

Para que la armazón bíblica quedase perfectamente aglutinada, solo faltaba un personaje que hiciera las veces de profeta neotestamentario; una voz que anunciase la Palabra; la bisagra que uniese la Segunda Edad con la Tercera y última. Después de un riguroso casting incaico, Garcilaso identificó en Huayna Cápac a un personaje idóneo para personificar a Juan Bautista.

Así, una tarde en la que el Inca Huayna Cápac osó mirar fija y largamente al dios Inti. El sumo sacerdote que acompañaba al inca reparó en su gesto temerario y, sin disimulos, le pidió que recatara su mirada ${ }^{34}$. Entonces, Huayna Cápac bajó los ojos, pero no pasó mucho tiempo para que los posara nuevamente en dirección al sol. El sumo sacerdote le reiteró al Inca su advertencia, recordándole no solo «de sernos prohibido el mirar con libertad a nuestro padre el sol», sino también del mal ejemplo que podía dar el inca a todos sus súbditos. La respuesta que el escritor cuzqueño puso en labios de Huayna Cápac -y que, a su vez, recogió del p. Acosta- puede ser considerada como una estupenda catequesis mistagógica:

El rey dijo entonces: «Pues yo te digo que este nuestro padre el Sol debe de tener otro mayor señor y más poderoso que no él. El cual le manda hacer este camino que cada día hace sin parar. Porque si él fuera el supremo señor una vez que otra dejara de caminar y descansara por su gusto, aunque no tuviera necesidad alguna» (CR, lib. IX, cap. X, p. 493).

La saga dinástica gloriosa de los incas llegaría a su fin con Huayna Cápac. Él fue el duodécimo inca en quien se cumpliría el oráculo del declive del impe-

\footnotetext{
33 Sobre la «pascua» incaica, véase un enfoque contrapuesto en C. Dean (2002, pp. 175-176). Sobre las festividades celebradas en el Cusco, recogidas por los primeros cronistas desde Juan de Betanzos hasta Bernabé Cobo (véase Cadène, 1998).

34 Nueva reminiscencia para el lector cristiano de aquella advertencia hecha a Moisés: «Mi rostro no podrás verlo, porque no puede verme el hombre y seguir viviendo» (Ex 33,20).
} 
rio. ${ }^{35}$ De hecho, el cisma imperial ya lo había decretado él mismo al dividir sus dominios entre sus hijos Huáscar, el primogénito y legítimo sucesor, y Atahualpa, su vástago quiteño que en los Comentarios reales adquiere un protagonismo villano. ${ }^{36}$ Cuando Huayna Cápac presintió que su final se aproximaba, mandó a llamar a los suyos para darles a conocer su testamento:

Certifícoos que, pocos años después que yo me haya ido de vosotros, vendrá aquella gente nueva y cumplirá lo que nuestro padre el sol nos ha dicho y ganará nuestro imperio y serán señores de él. Yo os mando que les obedezcáis y sirváis como a hombres que en todo os harán ventaja; que su ley será mejor que la nuestra y sus armas poderosas e invencibles, más que las vuestras $(\mathrm{CR}$, lib. IX, cap. XV, pp. 504-505).

\section{Los Comentarios reales: el exorcismo de un imperio}

La cercanía de Garcilaso a los círculos jesuitas -aunada a su temple espiritual, naturalmente inclinado hacia el recogimiento-, dejaría en él una huella profunda cuyo curso es perceptible en los Comentarios reales. Su tinta, incontaminada de moralina, alecciona con ingenio siguiendo una concepción ciceroneana de la historia. ${ }^{37}$ En efecto, en varios pasajes de la obra del prosista cuzqueño no pasa desapercibido cierto tono moralizador, en sintonía con buena parte de la producción literaria de la época (Suárez, 2015). Parafraseando a un autor contemporáneo, Garcilaso realiza «una larga y dura tarea de exorcismo» del imaginario europeo sobre la infidelidad religiosa del imperio incaico (Galeano, 2008, p. 121).

Al proponer, por ejemplo, la historia del conquistador Mancio Serra de Leguízamo, apostador empedernido, el Inca dio cuenta de cómo el pueblo se movilizó para rescatar al ludópata, nombrándolo alcalde, contra todo pronóstico. Teóricamente, había cierta lógica en tal elección: al ser alcalde, Serra estaría lo suficientemente ocupado como para no pensar en los juegos. Y, en efecto, tal fue la moraleja: «Donde se ve claro cuánto ayude la ociosidad al vicio y cuán de provecho sea la ocupación a la virtud» (CR, lib. III, cap. XX, p. 171). El afán moralizador del Inca se canalizó, muchas veces, a través de una elección con-

\footnotetext{
35 Número simbólico: doce fueron los patriarcas desde Sem hasta Jacob; como doce fueron los hijos de este último que formaron, a su vez, las doce tribus de Israel, prefiguración antonomástica de los doce apóstoles de Cristo.

36 Algunos académicos han propuesto que la rivalidad con el linaje de Atahualpa ante la guerra fratricida con Huáscar habría originado un trauma en Garcilaso que pudo haber sido uno de los móviles de la redacción de los Comentarios reales (Ortega, 2003). Este conflicto entre Cusco y Quito tuvo su origen cuando la sucesión incaica muchas veces oponía a más de un aspirante a la borla imperial (F. Pease, 1976).

37 «Historia vero testis temporum, lux veritatis, vita memoriae, nuntia vetustatis» [La historia es testigo de los tiempos, luz de la verdad, vida de la memoria, maestra de la vida, mensajera de la antigüedad] (Cicerón, 1967, p. 224).
} 
trastante de personajes: Los españoles transgredían con sus yerros morales la convivencia humana que los gobernantes incas se habían esmerado por preservar con castigos ejemplares. ${ }^{38}$ De alguna manera, estos últimos reeditaban a Moisés, legislando severamente para preservar una sociedad libre de vicios. ${ }^{39}$

Esta lectura metahistórica que Garcilaso realiza a la luz de la teología cristiana, como hemos dicho antes, presenta cierta dependencia del providencialismo y determinismo agustinianos (Serna, 2011, p. 147). ${ }^{40}$ El Inca, «férvido adalid de la fe cristiana y castellana» (Coello, 2009, p. 12), mantiene una postura perfectamente injertada en la doctrina patrística. No obstante, en los albores del s. XVII la narrativa garcilasista además de no ser políticamente correcta, pudo haber sido considerada heterodoxa. En efecto, muchos pasajes de los Comentarios reales no se ajustaban necesariamente a las indicaciones del Tercer Concilio de Lima (1582-1583), cuyas actas habían sido aprobadas en Roma (1588) y en Madrid (1591), muchos años antes de la publicación de los Comentarios reales, y que han sido recientemente editadas (Martínez, 2017).

Los decretos del Tercer Concilio Limense fueron promovidos desde España por Felipe II y encausados, in situ, por santo Toribio de Mogrovejo, segundo arzobispo de Lima. El texto conciliar fue muy claro en no contemplar coqueteo alguno con la religiosidad nativa. Y, aunque esto último no se ajustara necesariamente a la práctica, el Tercer Concilio Limense estableció una política de cero-tolerancia hacia cualquier tipo de componenda sincrética. Se intentaba evitar la contaminación pagana de la doctrina cristiana, por más que resonara aún el eco teológico de las semina Verbiti ; semillas que el Sembrador divino debió haber esparcido también en el campo del Tahuantinsuyo. ${ }^{42}$ Así, la cuestión quedó zanjada con la publicación de la Doctrina christiana, cuyo catecismo recogía pedagógicamente:

$$
\begin{aligned}
& \text { P. - [i]Dezidme, ay Dios? R. - Si, padre, Dios ay. } \\
& \text { P. - [i] Quantos Dioses ay? R. - Vno solo, no mas. }
\end{aligned}
$$

\footnotetext{
38 El Inca Garcilaso enumera las sentencias morales de Pachacútec en: CR, lib. VI, cap. XXXVI, pp. 349-351.

39 Sobre el Inca Manco Cápac, Garcilaso refirió lo siguiente: «Puso pena de muerte a los adúlteros y a los homicidas y ladrones. Mandoles que no tuviesen más de una mujer y que se casasen dentro en su parentela para que no se confundiesen los linajes. Y que se casasen de 20 años arriba, para que pudiesen gobernar sus casas y trabajar en sus haciendas» (CR, lib. I, cap. XXI, p. 57).

${ }^{40}$ Junto con los datos proporcionados por el jesuita José de Acosta en Historia natural y moral de las Indias (1590), Garcilaso se sirvió de las referencias vertidas por el agustino Jerónimo Román y Zamora en República del mundo (1575 y 1593), obra de la que pudo haber tomado también su visión agustiniana de la historia.

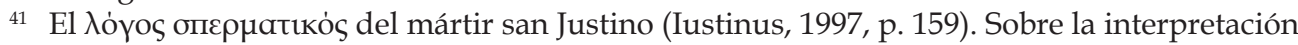
que mereció el apotegma del apologeta cristiano en el contexto colonial, véase: Prien (2013).

42 Entre los defensores de esta doctrina que dejaba abierta la justificación de los infieles destacaron en España Andrés Vega, Melchor Cano, Domingo de Soto y Francisco de Vitoria.
}

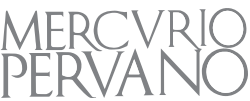


P. - [¿]Donde esta esse Dios? R. - En el cielo, y en la tierra, y en todo lugar.

P. - [i]Quien es Dios? R. - Es el Padre, y el Hijo, y el Spiritu Sancto que son tres personas y vn solo Dios (Tercer concilio limense, 1584, 13-14).

En realidad, en los Comentarios reales no hubo un pronunciamiento heterodoxo propiamente dicho ni mucho menos se contradijo algún dogma de la doctrina católica (Estenssoro, 2003). No obstante, una de las «herejías» de Garcilaso que la censura inquisitorial filtró tardíamente fue «su propia versión del Olimpo andino» (Millones, 2010) opuesta directamente a las directrices conciliares rubricadas por las autoridades eclesiásticas. Un caso sonado había sucedido en 1583: el jesuita mestizo Blas Valera había sido condenado a la reclusión por tiempo indeterminado en la prisión de su casa religiosa; durante los seis años que duraría su encarcelamiento, el sacerdote chachapoyano se dedicaría a la redacción de su monumental Historia Occidentalis, una de las fuentes del Inca. Como motivo de la sanción se adujo que el religioso había quebrantado su voto de castidad; sin embargo, los documentos de la Inquisición no hacían referencia a la supuesta fornicación del jesuita, sino que denunciaban la doctrina «herética» de sus escritos:

Sus obras alaban no solo el gobierno, cultura y enseñanzas de los incas, sino también la religión incaica, sugiriendo que el cristianismo andino debía incorporar muchos aspectos de la religiosidad nativa prehispánica. En efecto, su apología a la fe incaica confinaba peligrosamente con la herejía, una situación que los jesuitas, luchando contra los esfuerzos de la Inquisición para destruir a la Compañía en España, no podían tolerar (Hyland, 2003, p. 2).

A través de la Doctrina Christiana (1584) -primer libro impreso en América del Sur- los prelados americanos se declararon enemigos «de las ceremonias y ritos que usaban los indios conforme al tiempo de su infidelidad», tal y como reza el título de la Instrucción. Halagar la espiritualidad incaica, contemporizándola a la europea era preservarla del olvido e, indirectamente, justificarla o, eventualmente, fomentar su práctica. En cambio, si algo querían erradicar los prelados católicos era todo resabio idolátrico. Altamente sugestiva es, en este sentido, la lección catequética sobre el primer mandamiento del decálogo mosaico que los evangelizadores españoles transmitían a los indígenas penitentes:

P. - [i]Quien quebranta el ma[n]damie[n]to de ho[n]rar a Dios? R. - El que adora qualquiera criatura, o tiene ydolos, o guacas, o da credito a falsas sectas, y heregias, o sueños, y güeros, que son vanidad, y engaño del Demonio.

P. - Segun ello, [i]todas las ceremonias, que e[n]seña[n] los Indios viejos, y hechizeros, contra la ley de los christianos, son vanidad, y engaño del Demonio? R. - Asi es padre sin duda alguna, y los que las usan seran condenados con el Demonio (Tercer concilio limense, 1584, pp. 58-60). 
Aunque no la cite, Garcilaso conocía bien la Doctrina Christiana (Mazzotti, 2016). Entre otros motivos, porque en su elaboración había participado activamente el citado jesuita Blas Valera, por quien el Inca manifestó repetidamente un profundo respeto en varios pasajes de los Comentarios reales, y de cuyos «papeles rotos» se sirvió para alimentar la redacción de su obra. Sin embargo, la estima por el padre Valera no fue la excepción (Fernández, 2010). Por lo que se refiere a las referencias a congregaciones religiosas, Garcilaso muestra una predilección especial hacia la Compañía de Jesús cuyos miembros son «tan curiosos en todo» (CR, lib. IV, cap. XI, p. 197) que, gracias a ellos, «hay tanta abundancia de todas ciencias y de toda buena enseñanza de ellas como la que tienen y gozan» (CR, lib. II, cap. XXVIII, p. 130):

En los temas básicos el anciano clérigo Garcilaso, que tomó órdenes menores y vestía traje talar, es buen discípulo y cuasi vocero de la Compañía de Jesús. Una devoción pía y honesta baña su obra y se atiene, por propio testimonio, al consejo y lección de mentores y teólogos de la Compañía. Si en las crónicas quinientistas de Betanzos, Cieza, Molina el chileno, Santillán, es obvia la influencia dominica, lo es en Garcilaso la jesuita (Araníbar, 2016, p. 3).

La admiración hacia los hijos de Ignacio de Loyola es innegable, pero no deja de llamar la atención que el Inca fuera incluso más generoso en alusiones al fundador de la Orden de los Hermanos Menores. En efecto, se refirió a san Francisco de Asís llamándolo «bienaventurado patriarca» (CR, lib. VI, cap. VIII, p. 294) y «divino san Francisco» (CR, lib. VII, cap. VIII, p. 369; lib. VII, cap. XII, p. 379); no pudo encontrar mayor elogio para fray Antonio de san Miguel que el confirmarlo como «hijo verdadero de san Francisco» (CR, lib. VII, cap. XII, p. 380); y describió con detalle el episodio de una mujer de la realeza inca que pidió ser amortajada con el hábito de los franciscanos, con la esperanza de merecer un juicio eterno más benigno (CR, lib. VII, cap. XII, p. 381). Estas referencias apoyan ciertas hipótesis que señalan la afiliación del Inca a la Tercera Orden Franciscana (de la Fuente-Hontañón, 2010). Cuando en 1560 el Inca Garcilaso arribó a Montilla, debió haber atraído la curiosidad de los moradores de esta villa, cuna del franciscano Francisco Sánchez Solano, diez años menor que el Inca. Tanto al montillano como al cuzqueño los unirían muchos elementos en común: ambos fueron instruidos por los jesuitas, ambos gozaron del favor de los marqueses de Priego, ambos dejaron sus tierras para morir en un continente lejano al propio y, sobre todo, ambos ardieron en celos por cristianizar el mundo: el español con la cruz y el rabel; el peruano «con la espada y con la pluma». ${ }^{43}$ Francisco Solano se convertiría en uno de los santos más venerados en toda la América española; el Inca, en uno de sus escritores más laudados. Un trueque espléndido: el Nuevo

43 Importantes han sido los estudios heráldicos sobre el escudo nobiliario del Inca Garcilaso, cuya divisa reza: «Con la espada y con la pluma». Al respecto, véase R. Chang-Rodríguez (2013) y Fernández (2004). 
Mundo adoptó a quien le anunciaría el evangelio a través de sus encendidas prédicas; el Viejo Mundo, a quien develaría el protocristianismo incaico a través de sus palabras escritas.

El Inca murió el 23 de abril de 1616, adelantándose por poco a Miguel de Cervantes y a William Shakespeare; acaso el mes más enlutado de las letras euroamericanas. Y es que, más allá de las consideraciones teológicas y sociológicas que se derivan de su obra, cuando el Inca conquistó la lengua del conquistador, la hizo de todos (Vargas, 2010a, p. 28): Parafraseando a Chocano, en cada una de las páginas de los Cometarios reales, se siente latir su corazón.

\section{Referencias bibliográficas}

Albónico, A. (1996). El Inca Garcilaso, revisitado. Estudio y antología de las dos partes de los Comentarios reales. Roma: Bulzoni.

Amaya Farías, F. (2016). Comentarios teológicos a los Comentarios reales. Integración histórica y providencialismo teológico en el Inca Garcilaso. Quito: Abya-Yala.

Araníbar, C. (2009). «Hace 400 años, Comentarios reales». Libros \& Artes: Revista de Cultura de la Biblioteca Nacional del Perú, n. ${ }^{\circ} 32-33,2-5$.

Araujo, C. (2007). «Tumultuous Reading and Powerful Books: Aspects of Counter Reformation Culture in Portugal». En J. Carvalho (ed.), Religion and Power in Europe: Conflict and Convergence (pp. 221-234). Pisa: Edizioni Plus-Pisa University Press, 2007.

Arista Montoya, L. A. (1989). «Garcilaso Inca de la Vega o el tiempo histórico». Cuadernos Hispanoamericanos, n. ${ }^{\circ} 469-470,209-218$.

Atienza López, A. (2008). Tiempos de conventos: una historia social de las fundaciones en la España Moderna. Madrid: Marcial Pons-Universidad de La Rioja.

Bataillon, M. (1961). «Gutiérrez de Santa Clara, escrito mexicano». Nueva Revista de Filología Hispánica, XV, n. ${ }^{\circ} 3-4,405-440$.

Bernand, C. (2009). El Inca Garcilaso de la Vega o el nacimiento de la cultura mestiza de América. Lima: Ministerio de Relaciones Exteriores-Centro Cultural Inca Garcilaso-Centro Cultural de la Pontificia Universidad Católica del Perú.

Brading, D. (1986). «The Incas and the Renaissance: The Royal Commentaries of Inca Garcilaso de la Vega». Journal of Latin American Studies, XVIII, n. ${ }^{\circ}$, $1-23$.

Burckhardt, J. (2004) [1860]. La cultura del Renacimiento en Italia. Madrid: Ediciones Akal.

Cadène, Ch. (1998). «Les grandes fêtes incas au Cuzco» Caravelle: Cahiers du monde hispanique et luso-brésilien. n. ${ }^{\circ}$ 70, 55-72. 
Castro-Klarén, S. (2016). «Introduction». En Ch. Fernández y S. Castro-Klarén (eds.). Inca Garcilaso and Contemporary World-Making (pp. 3-19). Pittsburgh: University of Pittsburgh Press, 2016.

Chang-Rodríguez, R. (2006). «Introduction». En R.Chang-Rodríguez (ed.), Beyond Books and Borders: Garcilaso de la Vega and La Florida del Inca (pp. 15-32). Lewisburg: Bucknell University Press.

Chang-Rodríguez, R. (2010a) «Introducción». En R. Chang-Rodríguez (ed.). Entre la espada y la pluma. El Inca Garcilaso de la Vega y sus Comentarios reales (pp. 11-15). Lima: Fondo Editorial de la Pontificia Universidad Católica del Perú.

Chang-Rodríguez, R. (2010b). «La ruta del Inca Garcilaso». En R. Chang-Rodríguez (ed.). Entre la espada y la pluma. El Inca Garcilaso de la Vega y sus Comentarios reales (pp. 73-86). Lima: Fondo Editorial de la Pontificia Universidad Católica del Perú.

Chang-Rodríguez, R. (2013). Cartografía garcilasista. Murcia: Publicaciones de la Universidad de Alicante.

Cicerón (Marco Tulio) (1967). De oratore, I y II (Eds. E.W. Sutton y H. Rackham). Cambridge: Harvard University Press

Cieza de León, P. (1998) [1553]. The Discovery and Conquest of Peru (eds. A. Parma Cook y N. D. Cook). Durham-London: Duke University Press

Coello, Ó. (2009). «El «Inca» de los Comentarios reales: Descripción del Actante Ficcional». En C. Arrizabalaga Lizárraga y M. Prendes Guardiola (eds.). Este gran laberinto. Estudios filológicos en el centenario de los Comentarios reales (pp. 1-16). Lima: Universidad de Piura.

Cornejo Polar, A. (2000). «Garcilaso Inca de la Vega». En J. Cornejo Polar y A. Cornejo Polar (eds.). Literatura peruana siglo XVI a siglo XX (pp. 19-33). Lima-Berkeley: CELACP-Latinoamericana Editores.

Cortez, E. (2018). El Inca Garcilaso y el archivo colonial andino en el siglo XIX (pp. 209-254). Madrid: Iberoamericana-Vervuert.

Crowley, F. (1971). Garcilaso de la Vega, el Inca, and his sources in Comentarios Reales de los Incas (pp. 79-97). The Hague-Paris: Mouton.

De Betanzos, J. (2003) [1551]. Narrative of the Incas (eds. Roland Hamilton y D. Buchanan). Austin: University of Texas Press.

De la Fuente-Hontañón, R. (2010). «Estudio del testamento y codicilos del Inca Garcilaso de la Vega: primer humanista peruano (a. 1616)»: Revista de Derecho, XI, n. ${ }^{\circ} 11,193-224$.

De la Riva Agüero, J. (1908). Examen de la primera parte de los Comentarios reales de Garcilaso de la Vega. Lima: Oficina tipográfica de «La Opinión Nacional». 
De Solano, F. (1991). «Los nombres del Inca Garcilaso: Definición e identidad». Anuario de Estudios Americanos, n. ${ }^{\circ}$ 48, 121-150.

De Zárate, A. (1995) [1577]. Historia del Descubrimiento y Conquista del Perú (eds. F. Pease y T. Hampe). Lima: Fondo Editorial de la Pontificia Universidad Católica del Perú.

Dean, C. (2002). Los cuerpos de los incas y el Cuerpo de Cristo: el Corpus Christi en el Cuzco colonial. Lima: Universidad Nacional Mayor de San Marcos.

Del Pino-Díaz, F. (2010) «¿Dignidad cultural o proto-identidad cristiana de lo inca? Acerca del sentido preferente de los «comentarios» garcilasianos al Padre Acosta». En J. A. Mazzotti (ed.). Renacimiento mestizo: Los 400 años de los Comentarios reales (pp. 51-78). Madrid: Iberoamericana.

Del Pino-Díaz, F. (2014). «Humanismo romanista y paralelismo intercultural entre los anticuarios andaluces y el Inca Garcilaso». Histórica, XXXVIII, n. ${ }^{\circ}$, 7-32.

Del Pozo, M. (2012). «La traducción de Los Diálogos de Amor de León Hebreo: Notas para el entendimiento humano del Inca Garcilaso de la Vega». Entrehojas: Revista de Estudios Hispánicos, II, n. ${ }^{\circ}$ 1, 1-10.

Díez Torres, J. (2018). «La materia económica en La Florida del Inca y los Comentarios reales: testimonio colonial y discurso historiográfico». Hipogrifo. Revista de literatura y cultura del Siglo de Oro, n. ${ }^{\circ}$ 1, 217-231.

Dowling, L. (1996). «The Colonial Period». En D. W. Foster (Ed.). Mexican Literature: A History (pp. 31-81). Austin: University of Texas Press.

Durand, J. (1948). «La biblioteca del Inca». Nueva revista de Filología Hispánica, n. ${ }^{\circ}$ 3, 239-264.

Durand, J. (1963). «Garcilaso Between the World of the Incas and That of Renaissance Concepts». Diogenes, XI, n. ${ }^{\circ} 43,21-45$.

Duviols, P. (1958). «Sur le système religieux des Comentarios reales de los Incas». Annales de la Faculté des lettres d'Aix, n. ${ }^{\circ} 37,228-241$.

Duviols, P. (1964). «L'Inca Garcilaso de la Vega, interprète humaniste de la réligion incaïque». Diogène, n. ${ }^{\circ} 47,39-54$.

Duviols, P. (1988). «Los cultos incaicos y el humanismo cristiano en el Inca Garcilaso». En C. Goic (coord.). Historia y crítica de la literatura hispanoamericana, vol. 1: Época Colonial (pp. 189-195). Barcelona: Crítica.

Duviols, P. (1994). «Les Comentarios reales de Los Incas et la question du salut des infidèles». Caravelle. Cahiers du monde hispanique et luso-brésilien, n. ${ }^{\circ} 62$, 69-80.

Duviols, P. (2005). «¿Por qué y cómo Garcilaso heredó de su padre el título de Inca? Una lectura selectiva y comparativa de los Comentarios reales de los Incas y de algunos documentos garcilasistas». Histórica, XXIX, n. ${ }^{\circ}$ 2, 7-44. 
Eguiguren Callirgos, L. (2016). «Concordismo en los Comentarios reales». Mercurio Peruano, n. ${ }^{\circ}$ 529, 47-63.

Esperanza López Parada, E., Ortiz Canseco, M. y Paul Firbas, P. (eds.). (2016). La biblioteca del Inca Garcilaso de la Vega (1616-2016). Madrid: Biblioteca Nacional de España-Agencia Española de Cooperación Internacional.

Estenssoro Fuchs, J. C. (2003). Del paganismo a la santidad. La incorporación de los indios del Perú al Catolicismo, 1532-1750. Lima: Pontificia Universidad Católica del Perú-Instituto Riva Agüero-IFEA.

Fernández, Ch. (2004). Inca Garcilaso: imaginación, memoria e identidad. Lima: Fondo Editorial Universidad Nacional Mayor de San Marcos.

Fernández, Ch. (2010). «Traducción y apropiación: Los «papeles rotos» y la creación de Blas Valera como «autoridad» en los Comentarios reales del Inca Garcilaso». En C. de Mora, G. Serés y M. Serna (eds.). Humanismo, mestizaje y escritura en los Comentarios reales (pp. 79-92). Madrid: Iberoamericana Vervuert.

Fischer, D. H. (1996). The Great Wave: Price Revolutions and the Rhythm of History. New York: Oxford University Press.

Fuerst, J. W. (2000). Mestizo Rhetoric: The political thought of El Inca Garcilaso de la Vega (tesis doctoral). Harvard University.

Galeano, E. (2008). Espejos: Una historia casi universal. Madrid: Siglo XXI de España Editores.

Garcilaso de la Vega (Inca). (2015) [1609]. Obras Completas, vol. 2: Comentarios reales (ed. C. Araníbar). Lima: Ministerio de Relaciones Exteriores del Perú.

Garcilaso de la Vega (Inca) (1590). La traduzion del indio de los tres Dialogos de Amor de Leon Hebreo, hecha de italiano en español por Garcilasso Inga de la Vega, natural de la gran ciudad del Cuzco, cabeça de los Reynos y Provincias del Piru, dirigidos a la sacra Catolica Real Magestad del Rey don Felipe nuestro señor. Madrid, pp. 5-6.

Garramiola Prieto, E. (1993). «El Inca Garcilaso de la Vega, un hombre desengañado (nueva documentación sobre su etapa en Montilla)». Boletín de la Real Academia de Córdoba de Ciencias, Bellas Letras y Nobles Artes, n. ${ }^{\circ} 125$, 99-130.

González Vigil, R. (1990). Comentemos al Inca Garcilaso. Lima: Banco Central de Reserva del Perú.

Gruzinski, S. (2012). The Mestizo Mind: The Intellectual Dynamics of Colonization and Globalization (trad. D. Dusinberre). New York-London: Routledgeç.

Guardia, S. B. (2013). Mujeres peruanas. El otro lado de la historia. Lima: CEMHAL.

Guibovich Pérez, P.M. (2016) «La difusión del Inca Garcilaso de la Vega en los Andes», en E. López Parada, M. Ortiz Canseco y P. Firbas (eds.). La biblioteca del Inca Garcilaso de la Vega (1616-2016) (pp. 49-62). Madrid: Biblioteca Nacional de España-Agencia Española de Cooperación Internacional. 
Hampe Martínez, T. (1994). «El Renacimiento del inca revisitado: Los clásicos greco-latinos en su biblioteca y en su obra». Histórica, XVIII, n. ${ }^{\circ}$ 1, 69-94.

Heid, P. A. (1997). Rhetoric, Gender, and Narrative in the Comentarios reales de las Incas (tesis doctoral). University of California.

Huamán Zúñiga, R. F. (2009). «400 años de lecturas garcilasistas: Apuntes sobre la recepción crítica de los Comentarios reales de los incas». En C. Arrizabalaga Lizárraga y M. Prendes Guardiola (eds.). Este gran laberinto. Estudios filológicos en el centenario de los Comentarios reales (pp. 123-136). Lima: Universidad de Piura.

Hyland, S. (2003). The Jesuit and the Incas: The Extraordinary Life of Padre Blas Vale$r a$, S.J. Ann Arbor: The University of Michigan Press.

Iustinus (san Justino) (1997). The first and the second apologies. Ed. Leslie W. Barnard. New York: Paulist Press.

King, M. (1991). Le donne nel Rinascimento. Bari: Laterza.

Lohmann Villena, G. (1999). «Gutiérrez de Santa Clara, un gigante con pies de barro». Histórica, XXIII, n. ${ }^{\circ}$ 2, 329-337.

Macchi, F. (2009). Incas ilustrados: reconstrucciones imperiales en la segunda mitad del siglo XVIII. Madrid: Vervuert-Iberoamericana.

MacCormack, S. (2007). On the Wings of Time: Rome, the Incas, Spain, and Peru. New Jersey: Princeton University Press.

Mariátegui, J. C. (2007) [1928]. Siete ensayos de interpretación de la realidad peruana. Caracas: Biblioteca Ayacucho.

Martínez Cuesta, A. (1995). «Las monjas en la América Colonial, 1530-1824». Thesaurus: Boletín del Instituto Caro y Cuervo, L, n. ${ }^{\circ} 1-3,572-626$.

Martínez Ferrer, Luis (Ed.) (2017). Tercer Concilio Limense (1583-1591). Lima-Roma: Facultad de Teología Pontificia y Civil de Lima-Universidad Pontificia de la Santa Cruz.

Martínez Martínez, M. C. (2015). «Francisco López de Gómara y la Orden de Alcántara». Anuario de Estudios Americanos, LXXII, n. ${ }^{\circ} 1,151-176$.

Martínez-San Miguel, Y. (2008). From Lack to Excess: «minor» Readings of Latin American Colonial Discourse. Lewisburg: PA, Bucknell UP.

Mazzotti, J. A. (1996). Coros mestizos del Inca Garcilaso: resonancias andinas. Lima: Bolsa de Valores de Lima.

Mazzotti, J. A. (2010). «El Inca y la cruz: los Comentarios reales se persignan». En R. Chang-Rodríguez (ed.), Entre la espada y la pluma. El Inca Garcilaso de la Vega y sus Comentarios reales (pp. 87-94). Lima: Fondo Editorial de la Pontificia Universidad Católica del Perú. 
Mazzotti, J. A. (2016). «Problemas con la Primera Edad: Apuntes sobre el saber andino en los Comentarios reales». En E. López Parada, M. Ortiz Canseco y P. Firbas (eds.), La biblioteca del Inca Garcilaso de la Vega (1616-2016) (pp. 63-74). Madrid: Biblioteca Nacional de España-Agencia Española de Cooperación Internacional.

Méndez Gastelumendi, C. (1996). «Incas Sí, Indios No, Notes on Peruvian Creole Nationalism and Its Contemporary Crisis». Journal of Latin American Studies, XXVIII, n. ${ }^{\circ} 1,197-225$.

Menéndez y Pelayo, M. (2008). Historia de la poesía hispanoamericana, vol. 2 (Ed. de E. Sánchez Reyes). Alicante: Biblioteca Virtual Miguel de Cervantes.

Millones, L. (2010). «Las herejías de Garcilaso». En J. A. Mazzotti (ed.), Renacimiento mestizo: Los 400 años de los Comentarios reales (pp. 159-180). Madrid: Iberoamericana.

Miró Quesada Sosa, A. (1971). El Inca Garcilaso y otros estudios garcilasistas. Madrid: Ediciones Cultura Hispánica.

Myers, K. A. (2007). Fernández de Oviedo's Chronicle of America: A New History for a New World. Austin: University of Texas Press.

Nauss Millay, A. (2005). Voices from the Fuente Viva: The Effect of Orality in Twentieth-Century Spanish-American Narrative. Lewisburg: Bucknell University Press.

Neira, H. (2009). Garcilaso, testigo de vida. Lima: Biblioteca Nacional del Perú.

No, S. (2006). «La oralidad garcilasista en los Comentarios reales de los incas». Perspectivas Latinoamericanas, n. $^{\circ} 3,161-172$.

Ortega, F. (2003). «Trauma and Narrative in Early Modernity: Garcilaso's Comentarios reales, 1609-1616». Hispanic Issue, CXVIII, n. ${ }^{\circ} 2$, 393-426.

Oviedo Pérez de Tudela, R. (2010). «Desde la orilla española: Modelos y huellas de los Comentarios reales». En R. Chang-Rodríguez (ed.), Entre la espada y la pluma. El Inca Garcilaso de la Vega y sus Comentarios reales (pp. 149-170). Lima: Fondo Editorial de la Pontificia Universidad Católica del Perú.

Parra, R. (2014). The Tyranny of the Inca: The Inca Garcilaso de la Vega's Humanism and the Political Writing in Colonial Peru (1568-1617) (Tesis doctoral), New York University.

Pease, F. (1976). Los últimos Incas del Cusco. Lima: P. L. Villanueva.

Pease, F. (1999). «Temas clásicos en las crónicas peruanas de los siglos XVI y XVII». En T. Hampe Martínez (comp.). La tradición clásica en el Perú virreinal (pp. 17-34). Lima: Fondo Editorial Universidad Nacional Mayor de San Marcos.

Porras Barrenechea, R. (1946). El Inca Garcilaso de la Vega (1539-1616). Lima: Editorial Lumen.

Porras Barrenechea, R. (1950). «Investigaciones en Montilla sobre el Inca Garcilaso, San Francisco Solano y Cervantes». Boletín de la Real Academia de Ciencias, Bellas Letras y Nobles Artes de Córdoba, n. ${ }^{\circ}$ 63, 15-44. 
Porras Barrenechea, R. (1962). Los cronistas del Perú, 1528-1650. Lima: Sanmartí Impresores.

Prescott, W. H. (2005) [1843]. The History of the Conquest of Mexico E Peru, vol. 2. New York: Cosimo Classics.

Prien, H. J. (2013). Christianity in Latin America. Leiden-Boston: Brill.

Rodríguez Garrido, J. A. (1995). «La identidad del enunciador en los Comentarios reales». Revista Iberoamericana, n. ${ }^{\circ} 172-173,371-383$.

Rodríguez Garrido, J. A. (2016). «El último libro del Inca Garcilaso». En E. López Parada, M. Ortiz Canseco y P. Firbas (eds.). La biblioteca del Inca Garcilaso de la Vega (1616-2016) (pp. 75-92). Madrid: Biblioteca Nacional de España-Agencia Española de Cooperación Internacional.

Rostworowski de Diez Canseco, M. (1999). Historia del Tahuantinsuyu. Lima: Instituto de Estudios Peruanos.

Sánchez, A. (1993). «Ángela Carranza, alias Ángela de Dios. Santidad y poder en la sociedad virreinal peruana (s. XVII)». En G. Ramos y H. Urbano (comps.), Catolicismo y extirpación de idolatrías, siglos XVI-XVIII (pp. 236-292). Cusco: Centro de Estudios Regionales Andinos Bartolomé de Las Casas.

Sánchez, L. A. (1979). Garcilaso Inca de la Vega, primer criollo. Lima: Fondo del Libro del Banco de los Andes.

Santos Chocano, J. (1962) Antología poética. Madrid: Espasa-Calpe.

Saranyana, J. I. (dir.) y Alejos-Grau, C. J. (coord.) (1996), Historia de la teología latinoamericana. Primera parte: Siglos XVI y XVII. Pamplona: Eunate.

Serna, M. (2000) [1609]. «Introducción», en Garcilaso de la Vega (Inca), Comentarios reales (pp. 9-81). Madrid: Editorial Castalia.

Serna, M. (2011). «Pensamiento medieval y renacentista en el Inca Garcilaso de la Vega». En J. Morales Saravia y G. Penzkofer (eds.). El Inca Garcilaso de la Vega: entre varios mundos (pp. 147-162). Lima: Fondo Editorial Universidad Nacional Mayor de San Marcos.

Silva Santisteban, R. (2010). «Garcilaso de la Vega traductor». Mutatis Mutandis, III, n. ${ }^{\circ} 2,235-248$.

Suárez Miramón, A. (2015). La construcción de la modernidad en la literatura española. Madrid: Editorial Centro de Estudios Ramón Areces.

Tercer Concilio Limense (1584), Doctrina christiana, y catecismo para instruccion de los indios, y de las de mas personas, que han de ser enseñadas en nuestra sancta fe. Con vn confessionario, y otras cosas necessarias para los que doctrinan, que se contienen en la pagina siguiente. Compuesto por auctoridad del Concilio Prouincial, que se celebro en la Ciudad de los Reyes, el año de 1583. Y por la misma traduzido en las dos lenguas generales, de este reyno, quichua, y aymara. Ciudad de los Reyes, Antonio Ricardo, 1584. 
Turner, T. (1988). «Ethno-ethnohistory: Myth and History in Native South American Representations of Contact with Western Society» (pp. 235-281). En M. Luthfi y J. D. Hill (eds.). Rethinking history and myth: indigenous South American perspectives on the past. Urbana: University of Illinois Press.

van Deusen, N. (2001). Between the Sacred and the Worldly: The Institutional and Cultural Practice of Recogimiento in Colonial Lima. Stanford: Stanford University Press.

Vargas Llosa, M. (2010a). «El Inca Garcilaso y la lengua de todos». En R. Chang-Rodríguez (ed.), Entre la espada y la pluma. El Inca Garcilaso de la Vega y sus Comentarios reales (pp. 19-30). Lima: Fondo Editorial de la Pontificia Universidad Católica del Perú.

Vargas Llosa, M. (2010b) «Mario Vargas Llosa conversa sobre el Inca Garcilaso con Raquel Chang Rodríguez». En R. Chang-Rodríguez (ed.), Entre la espada y la pluma. El Inca Garcilaso de la Vega y sus Comentarios reales (pp. 193199). Lima: Fondo Editorial de la Pontificia Universidad Católica del Perú.

Vargas Llosa, M. (2016). «El primer peruano». En E. López Parada, M. Ortiz Canseco y P. Firbas (eds.). La biblioteca del Inca Garcilaso de la Vega (1616-2016) (pp. 13-18). Madrid: Biblioteca Nacional de España-Agencia Española de Cooperación Internacional.

Varón Gabai, R. (2008). «Pedro Pizarro (ca. 1513-1587) ». En J. Pillsbury (ed.), Guide to Documentary Sources for Andean Studies, 1530-1900 (pp. 524-528), vol. 2. Norman (Oklahoma): National Gallery of Art-University of Oklahoma Press.

Vergara Ciordia, J. (2005). «El Seminario Conciliar en la América Hispana (15631800) ». En J. I. Saranyana (dir.) y C. J. Alejos-Grau (coord.). Historia de la teología latinoamericana, vol. II/1: Escolástica Barroca, Ilustración y preparación de la Independencia (1665-1810) (pp. 99-184). Madrid-Frankfurt am Main: Iberoamericana-Vervuert.

Von Hagen, A. (2015). «Valera, Blas». En G. Urton y A. von Hagen (eds.). Encyclopedia of the Incas. Lanham: Rowman \& Littlefield.

Ward, Th. (2010). «Modern Nativist Readings of Garcilaso in Peru». En R. Chang-Rodríguez (ed.), Entre la espada y la pluma. El Inca Garcilaso de la Vega y sus Comentarios reales (pp. 171-189). Lima: Fondo Editorial de la Pontificia Universidad Católica del Perú.

Zamora, M. (1988). Language, Authority, and Indigenous History in the Comentarios Reales de los Incas. Cambridge: Cambridge University Press.

Zanelli, C. (2016). «Las fábulas de Garcilaso: ¿alegoría, historia o ficción en los Comentarios reales?». Histórica, XL, n. ${ }^{\circ} 2,421-433$. 